\title{
ANALISA FAKTOR PENYEBAB RENDAHNYA KINERJA PERAWAT PELAKSANA DI RUMAH SAKIT KOTA MEDAN
}

\author{
Kristina L Silalahi ${ }^{1}$, Patimah Sari Siregar ${ }^{2}$ \\ ${ }^{1,2}$ Faklutas Keperawatan dan Kebidanan, Universitas Prima Indonesia \\ Email:kristinasilalahi@unprimdn.ac.id
}

\begin{abstract}
Hospital is a health service with excellent and competitive service demands by its users. The function of the hospital was developed by the guidance of science and technology at its time. Performance appraisal is the most reliable tool for managers to control human resources and productivity and can be used effectively to direct employee behavior to produce nursing services based on high quality and quantity. The purpose of this study was to analyze the factors causing the low performance of nurses in Medan city hospital. This type of research is a quantitative study with a cross-sectional study design. This research was conducted at the Royal Prima Medan Hospital in July. The sample in this study were all nurses who served in the inpatient room. The sampling technique in this study using saturated sampling techniques totaling 159 nurses. Data collection using a questionnaire with the chi-square test. The results showed that the three-dimensional factors of nurse performance had a relationship with the performance of nurses, namely individual factors $p=0.000$, psychological factors $p=0.006$, and organization $p=$ 0.002. This research concludes that the majority of nurses in the hospital still have low performance. The researcher's suggestion for the hospital is that the hospital pays more attention to the performance of the nurses who work in the inpatient room.
\end{abstract}

Keyword: performance, nurse, hospital

\section{PENDAHULUAN}

Saat ini rumah sakit berada dalam suasana global dan kompetitif yang sangat tinggi tingkat persaingan layanan kesehatannya sehingga menuntut mutu pelayanan rumah sakit yang harus dikelola dengan dasar konsep manajemen yang jelas dan terarah. Fungsi rumah sakit berkembang sesuai dengan tuntunan ilmu pengetahuan dan teknologi. Peran dan fungsi rumahsakit yang begitu komplek menuntut tersedianya sumber daya manusia (SDM) dalam rumah sakit yang kompeten dan memiliki kinerja yang baik.
Rumah sakit dituntut untuk meningkatkan mutu pelayanan baik kualitas maupun kuantitas pelayanan kesehatan karena semakin kompetetifnya persaingan antar rumah sakit untuk merebut hati pasien. Rumah sakit harus meningkatkan pelayanannya yang berorientasi kepada pemenuhan kebutuhan pasien karena tanpa memperhatikan kebutuhan konsumen (pasien dan keluarganya), rumah sakit akan ditinggalkan oleh konsumennya. Pasien menjadi sangat selektif dalam memilih rumah sakit berdasarkan mutu pelayanan yang diberikannya oleh tenaga kesehatan. 
Penilaian kinerja merupakan alat yang paling dapat dipercaya oleh manager perawat dalam mengontrol sumber daya manusia dan produktivitas (Swansburg, 2001). Proses penilaian kinerja dapat digunakan secara efektif untuk mengarahkan perilaku pegawai dalam rangka menghasilkan jasa keperawatan berdasarkan kualitas dan kuantitas yang tinggi (Nursalam, 2011).

Kreitner dan Kinicki, (2014) mengemukakan bahwa ada 3 (tiga) faktor yang berpengaruh terhadap kinerja, yaitu: 1) Faktor individu meliputi kemampuan, keterampilan, latar belakang keluarga, pengalaman kerja, tingkat sosial dan demografi seseorang, 2) Faktor psikologi meliputi persepsi, peran, sikap, kepribadian, motivasi dan kepuasan kerja, dan 3) Faktor organisasi meliputi struktur organisasi, desain pekerjaan, kepemimpinan, sistem penghargaan.

Perawat menjadi salah satu profesi yang paling banyak ditemukan rumah sakit. Menurut UU Kesehatan No. 36 Tahun 2009 Pasal 23 tenaga kesehatan berwenang untuk menyelenggarakan pelayanan kesehatan, dimana sekitar 40$60 \%$ pelayanan di rumah sakit merupakan pelayanan keperawatan dan jumlah perawat di dalam rumah sakit harus sama dengan jumlah tempat tidur untuk rumah sakit tipe $A$ dan B sedangkan rumah sakit tipe $\mathrm{C}$ memiliki jumlah perawat $2 / 3$ dari jumlah tempat tidur (Republik Indonesia, 2009).

Tujuan penelitian ini adalah untuk memperoleh informasi tentang faktor apa yang menyebabkan rendahnya kinerja perawat pelaksana di rumah sakit kota medan. Faktor yang akan dijadikan sebagai instrumen dalam penelitian ini untuk menilai kinerja perawat pelaksana adalah faktor variabel individu, variabel organisasi dan variabel psikologis (Rivai, 2013).

Penelitian yang sama pernah dilakukan oleh Supriadi (2017) tentang faktor-faktor yang berhubungan dengan kinerja perawat di Rumah Sakit Islam PDHI Yokyakarta didapatkan bahwa variabel yaitu motivasi, etos kerja, lingkungan kerja, kompetensi dan kepuasan kerja mempengaruhi kinerja perawat.

Permasalahan rendahnya kinerja perawat di rumah sakit saat ini merupakan permasalahan yang harus segera diselesaikan, karena kinerja merupakan indikator penilaian untuk kualitas atau mutu suatu layanan kesehatan dirumah sakit. Kinerja yang kurang akan berdampak kepada kepuasan pasien dan kualitas pelayanan

Berdasarkan latar belakang di atas maka peneliti tertarik untuk melakukan penelitian tentang Analisa Faktor Penyebab Rendahnya Kinerja Perawat Pelaksana di Rumah Sakit Kota Medan. 


\section{METODE}

Jenis penelitian ini adalah penelitian kuantitatif dengan desain penelitian cross sectional study. Penelitian ini dilaksanakan di Rumah Sakit Royal Prima Medan dikarenakan masih tingginya komplain pasien terhadap pelayanan perawat.

Sampel dalam penelitian ini adalah seluruh perawat pelaksana yang bertugas diruang rawat inap lebih dari 3 tahun berjumlah 159 perawat pelaksana. Teknik pengambilan sampel dalam penelitian ini dengan menggunakan teknik sampling jenuh (Arikunto, 2012). Penelitian ini akan dilakukan pada bulan Juli tahun 2020.

Metode pengumpulan data dengan menggunakan kuesioner. Kuesioner dibagikan kepada perawat berisikan tentang faktor-faktor yang mempengaruhi kinerja perawat terdiri dari faktor individu, psikologi dan faktor organisasi. Kuesioner dalam penelitian ini diisi langsung oleh perawat pelaksana pada saat jam istrahat. Metode analisis data dalam penelitian ini dengan menggunakan uji chi-square.

\section{HASIL DAN PEMBAHASAN}

Hasil penelitian yang telah dilakukan kepada 159 perawat di rumah sakit dapat dijelaskan sebagai berikut:
Tabel 1. Distribusi Karakteristik

Frekuensi Pelaksana

\begin{tabular}{|c|c|c|c|}
\hline No & Karakteristik & $\begin{array}{c}\text { Frekuensi } \\
(f)\end{array}$ & $\begin{array}{c}\text { Persentase } \\
(\%)\end{array}$ \\
\hline \multirow[t]{6}{*}{1} & Umur & & \\
\hline & $<31$ tahun & 25 & 15,7 \\
\hline & 31-40 tahun & 68 & 42,8 \\
\hline & 41-50 tahun & 59 & 37,1 \\
\hline & $>50$ tahun & 7 & 4,4 \\
\hline & Total & 159 & 100 \\
\hline \multirow[t]{4}{*}{2} & Jenis Kelamin & & \\
\hline & Laki-Laki & 48 & 30,2 \\
\hline & Perempuan & 111 & 69,2 \\
\hline & Total & 159 & 100 \\
\hline \multirow[t]{4}{*}{3} & Lama Bekerja & & \\
\hline & $<1$ tahun & 48 & 31 \\
\hline & $>1$ tahun & 109 & 69 \\
\hline & Total & 159 & 100 \\
\hline \multirow[t]{4}{*}{4} & Pendidikan & & \\
\hline & D3 & 69 & 43,4 \\
\hline & S1+Ners & 141 & 56,6 \\
\hline & Total & 159 & 100 \\
\hline
\end{tabular}

Berdasarkan karakteritik perawat pelaksana diperoleh data mayoritas perawat berada pada rentang usia 31-40 tahun (42,8\%), berdasarkan jenis kelamin perawat pelaksana lebih banyak berjenis kelamin perempuan yaitu sebanyak 111 (69,8\%), berdasarkan lama bekerja perawat pelaksana paling banyak berada bekerja lebih dari 1 tahun sebanyak 109 (69\%), berdasarkan pendidikan perawat perawat pelaksana paling banyak adalah lulusan S1+Ners yaitu sebanyak $141(56,6 \%)$.

Tabel 2. Kinerja Perawat Pelaksana

\begin{tabular}{lrr}
\hline $\begin{array}{c}\text { Kinerja } \\
\text { Perawat } \\
\text { Pelaksana }\end{array}$ & $\begin{array}{r}\text { Frekuensi } \\
(\boldsymbol{f})\end{array}$ & $\begin{array}{r}\text { Persentase } \\
(\boldsymbol{\%})\end{array}$ \\
\hline Baik & 44 & 25,9 \\
Kurang & 115 & 75,1 \\
Baik & & \\
\hline \multicolumn{1}{c}{ Jumlah } & 159 & 100.0 \\
\hline
\end{tabular}


Hasil penelitian menunjukkan bahwa kinerja perawat pelaksana mayoritas memiliki kinerja pada kategori kurang baik sebesar 115 orang $(75,1 \%)$ dan minoritas kinerja berada pada kategori baik sebesar 44 orang $(25,9 \%)$.

Tabel 3. Distribusi Dimensi Kinerja Perawat Pelaksana

\begin{tabular}{llrrr}
\multirow{2}{*}{$\begin{array}{l}\text { Dimensi } \\
\text { Kinerja } \\
\text { Perawat }\end{array}$} & \multicolumn{2}{c}{ Tidak baik } & \multicolumn{2}{c}{ Baik } \\
\cline { 2 - 5 } & \multicolumn{1}{c}{$\boldsymbol{f}$} & \multicolumn{1}{c}{$\boldsymbol{r}$} & \multicolumn{1}{c}{$\boldsymbol{\%}$} \\
\hline Individu & 132 & 83 & 27 & 17 \\
Psikologi & 135 & 84.9 & 24 & 15.1 \\
Organisasi & 137 & 86.2 & 22 & 13.8 \\
\hline
\end{tabular}

Berdasarkan hasil penelitian pada Tabel distribusi dimensi kinerja perawat pelaksana menunjukkan bahwa mayoritas dimensi kinerja perawat berada dalam kategori tidak baik baik yang terdiri dari faktor individu sebanyak 132 orang (83\%), faktor psikologi sebanyak 135 orang $(84,9 \%)$ dan faktor organisasi sebanyak 137 orang $(86,2 \%)$.

Tabel 4. Analisa Faktor Penyebab Rendahnya Kinerja Perawat Pelaksana di Rumah Sakit Kota Medan

\begin{tabular}{|c|c|c|c|c|c|c|c|}
\hline \multirow{3}{*}{ Variabel } & \multicolumn{6}{|c|}{ Kinerja Perawat } & \multirow{3}{*}{$\boldsymbol{P}$} \\
\hline & \multicolumn{2}{|c|}{ Baik } & \multicolumn{2}{|c|}{ Kurang Baik } & \multicolumn{2}{|c|}{ Jumlah } & \\
\hline & $f$ & $\%$ & $f$ & $\%$ & $\mathbf{N}$ & $\%$ & \\
\hline \multicolumn{8}{|l|}{ Individu } \\
\hline Kurang Baik & 32 & 13 & 100 & 87 & 132 & 100 & 0,000 \\
\hline Baik & 12 & 45 & 15 & 55 & 27 & 100 & \\
\hline \multicolumn{8}{|l|}{ Psikologis } \\
\hline Kurang Baik & 32 & 12 & 103 & 88 & 135 & 100 & 0,006 \\
\hline Baik & 12 & 40 & 15 & 60 & 27 & 100 & \\
\hline \multicolumn{8}{|l|}{ Organi-sasi } \\
\hline Kurang Baik & 30 & 10 & 117 & 90 & 137 & 100 & 0,002 \\
\hline Baik & 14 & 51 & 13 & 49 & 27 & 100 & \\
\hline
\end{tabular}

Berdasarkan hasil chi square menunjukan bahwa ketiga faktor dimensi kinerja perawat memiliki hubungan dengan kinerja perawat yang yang terdiri dari faktor individu dengan nilai $p=0,000$, faktor psikologis dengan nilai $p=0,006$, dan faktor organisasi dengan nilai $p=0,002$.

\section{Pembahasan}

Hasil penelitian menunjukkan bahwa kinerja perawat pelaksana mayoritas memiliki kinerja kurang baik sebesar
115 orang $(75,1 \%)$ dan minoritas kinerja baik sebesar 44 orang $(25,9 \%)$. dan hasil uji chi square menunjukan faktor individu $p=0,000$, faktor psikologis $p=0,006$ dan faktor organisasi $p=0,002$ yang artinya ada hubungan dimensi kinerja perawat dengan rendahnya kinerja perawat pelaksana.

Penilaian kinerja merupakan indikator yang paling utama dalam meningkatkan mutu suatu layanan. Kinerja yang buruk akan sangat 
berpengaruh terhadap kepuasan pasien di rumah sakit. Kinerja yang kurang dari pekerja di layanan kesehatan sangat mempengaruhi kualitas suatu kesehatan.

Institusi layanan kesehatan perlu melakukan penilaian kinerja secara berkesinambungan dan menetap, hal dilakukan dengan harapan dapat menjaga konsistensi dan kualitas mutu layanan kesehatan khususnya layanan keperawatan.

Beberapa data penelitian mendapatkan bahwa ada beberapa perawat yang sama sekali belum pernah dilakukan penilaian kinerja selama menjadi perawat di rumah sakit, ada juga beberapa perawat yang hanya mengatakan bahwa penilaian kinerja hanya dilakukan apabila ada kebutuhan saja atau penilaian kinerja yang situasional. Berdasarkan pengalaman peneliti selama melakukan di rumah sakit, peneliti menemukan beberapa perawat yang mengatakan bahwa tidak adanya reward atau bonus bagi perawat yang memiliki kinerja yang baik.

Peneliti juga melakukan tanya-jawab kepada beberapa perawat tentang apa saja yang mempengaruhi kinerja saat melakukan pekerjaannya sehari-hari. Kebanyakan perawat menjawab bahwa organisasi merupakan faktor yang paling sering mempengaruhi kinerja perawat. Perawat merasa kurang nyaman bekerja di tempat kerjanya dan perlakuan organisasi yang masih kurang kepada perawat.

Sebagian perawat juga mengatakan bahwa faktor psikologi juga sangat mempengaruhi kinerja perawat. Perawat sering merasa kurang bersemangat dalam melakukan pekerjaannya setiap hari. Apalagi saat perawat dinas malam, terkadang hanya seperti pindah tempat istrahat saja dimalam hari. Perhatian perawat terhadap pasien berbeda ketika malam hari dengan dinas di pagi hari.

Hasil penelitian mendapatkan bahwa perawat memiliki semangat bekerja yang kurang karena mendapatkan perlakuan dari atasan yang kurang menghargai kinerja perawat. Apalagi sering dikaitkan terhadap upah perawat yang masih ada dibawa upah minimum pegawai. Perawat juga mengatakan banyaknya pemotongan yang perawat tidak ketahui.

Menurut penelitian Maimun dan Yelina (2016) menjelaskan bahwa kompensasi atau penghargaan yang diberikan oleh organisasi akan berdampak pada kinerja perawat di Rumah Sakit Bhayangkara Pekanbaru.

Penelitian Supriadi (2017) menjelaskan bahwa variabel yaitu motivasi, etos kerja, organisasi, kompetensi dan kepuasan kerja mempengaruhi kinerja perawat. Kepuasan merupakan faktor yang paling 
dominan mempengaruhi kinerja perawat pelaksana di Rumah Sakit.

Lingkungan kerja juga merupakan faktor yang sangat mempengaruhi kinerja perawat pelaksana. Lingkungan yang nyaman, kondusif dan mendukung pekerjaan kita akan sangat mempengaruhi semangat bekerja. Lingkungan kerja yang tidak kondusif bukan hanya dilihat dari fasilitas, namum dapat dilihat juga dari segi iklim kerja ditempat kita bekerja. Iklim lingkungan kerja yang baik akan mendorong semangat kerja yang baik, sehingga akan tercipta kualitas kerja yang baik atau tinggi.

Asumsi peneliti terhadap hasil penelitian adalah rumah sakit perlu memberikan penghargaan atau kompensasi yang sesuai dengan beban kerja perawat, karena dengan diberikannya kompensasi ataupun penghargaan diharapkan akan dapat meningkatkan kinerja perawat di rumah sakit terutama di ruang rawat inap. Institusi layanan kesehatan juga perlu melakukan penilaian kinerja secara konsisten dan berkesinambungan kepada seluruh perawat pelaksana.

\section{KESIMPULAN DAN SARAN}

\section{Kesimpulan}

Adapun yang menjadi kesimpulan dalam penelitian ini adalah:
1. Kinerja perawat pelaksana di rumah sakit mayoritas berada pada kategori tidak baik.

2. Faktor penyebab rendahnya kinerja perawat pelaksana di rumah sakit mayoritas berada pada dimensi individu, psikologis dan organisasi.

\section{Saran}

Bagi rumah sakit agar meningkatkan kinerja perawat melalui pelatihan dan seminar keperawatan, serta pihak rumah sakit lebih memberikan perhatian dan penghargaan terhadap kinerja perawat di rumah sakit. Pihak rumah sakit juga perlu melakukan penghargaan atau reward terhadap pegawai yang memiliki kinerja baik dalam melakukan pekerjaannya sebagai perawat pelaksana di rumah sakit.

\section{UCAPAN TERIMA KASIH}

Terima kasih peneliti sampaikan kepada Kementerian Riset, Teknologi, dan Pendidikan Tinggi yang telah memberikan kesempatan untuk mendapatkan hibah penelitian Dosen Pemula (PDP) dan Kepada LPPM UNPRI yang telah memfasilitasi peneliti dalam melaksanakan penelitian ini dari awal sampai selesai.

\section{DAFTAR PUSTAKA}

Arikunto, S. (2012). Prosedur penelitian: Suatu pendekatan praktik (Edisi Revisi). Jakarta: Rineka Cipta. Kreitner, R., \& Kinicki, A. (2014). 
Perilaku Organisasi: Organizational Behavior.

Maimun, N., \& Yelina, A. (2016). Kinerja keperawatan di Rumah Sakit Bhayangkara Pekanbaru. Jurnal Kesehatan Komunitas. https://doi.org/10.25311/jkk.vol3.iss2 .104

Nursalam. (2011). Manajemen keperawatan aplikasi dalam Praktik keperawatan profesional. Edisi 3. Jakarta: Salemba Medika.

Republik Indonesia. UU RI No. 36 Tahun 2009 Tentang Kesehatan.

Rivai, V. (2013). Performance appraisal: Sistem yang tepat untuk menilai kinerja karyawan dan meningkatkan daya saing perusahaan. Jakarta: PT RajaGrafindo Persada.

Supriadi, S. (2017). Faktor-faktor yang berhubungan dengan kinerja Perawat di Rumah Sakit Islam PDHI Yogyakarta. Health Sciences and Pharmacy Journal. https://doi.org/10.32504/hspj.vli1.4

Swansburg, R. C. (2001). Pengembangan staf keperawatan: suatu pengembangan sumber daya manusia. Jakarta: EGC. 